University of Nebraska - Lincoln

DigitalCommons@University of Nebraska - Lincoln

History and dating of the publication of the Philadelphia (1822) and London (1823) editions of Edwin James's Account of an expedition from Pittsburgh to the Rocky Mountains

Neal Woodman

USGS Patuxent Wildlife Research Center, woodmann@si.edu

Follow this and additional works at: https://digitalcommons.unl.edu/usgsstaffpub

Woodman, Neal, "History and dating of the publication of the Philadelphia (1822) and London (1823) editions of Edwin James's Account of an expedition from Pittsburgh to the Rocky Mountains" (2010). USGS Staff -- Published Research. 582.

https://digitalcommons.unl.edu/usgsstaffpub/582

This Article is brought to you for free and open access by the US Geological Survey at DigitalCommons@University of Nebraska - Lincoln. It has been accepted for inclusion in USGS Staff -- Published Research by an authorized administrator of DigitalCommons@University of Nebraska - Lincoln. 


\title{
History and dating of the publication of the Philadelphia (1822) and London (1823) editions of Edwin James's Account of an expedition from Pittsburgh to the Rocky Mountains
}

\author{
NEAL WOODMAN
}

USGS Patuxent Wildlife Research Center, MRC-111, National Museum of Natural History, Smithsonian Institution, PO Box 37012, Washington, DC 20013-7012, USA (e-mail: woodmann@si.edu).

\begin{abstract}
The public record of Major Stephen H. Long's 1819-1820 exploration of the American north-west, Account of an expedition from Pittsburgh to the Rocky Mountains, compiled by Edwin James, contains valuable contributions regarding the natural landscapes, native peoples and wildlife of a mostly unexplored region of the American west compiled from the notes of some of America's foremost naturalists, and it includes the first descriptions of 67 new species. The original plan was to publish the Account in Philadelphia and London simultaneously, yet these two editions differ substantially in ways that are relevant to the taxonomic contributions in the work. It is generally assumed that the Philadelphia edition was published in early January 1823 and was available first, but little substantive evidence has been presented to support its priority over the London edition. Review of contemporary correspondence and periodicals indicates the Philadelphia edition was available and for sale on 31 December 1822, whereas the London edition was available in late February 1823. As previously assumed by most sources, the Philadelphia edition has priority of publication and is the authority for most species names. Its correct year of publication, however, is 1822 rather than 1823 .
\end{abstract}

KEY WORDS: Stephen Harriman Long - Thomas Say- North America - exploration - nomenclature publication history - taxonomy.

\section{INTRODUCTION}

The scientists, engineers and artists who formed the core of Major Stephen Harriman Long's expedition to the Rocky Mountains (1819-1820) originally were an arm of a thousand-man military force known as the Missouri Expedition, which had been authorized to move up the Missouri River to the mouth of the Yellowstone River in order to secure the north-western frontier against British influence, support the American fur trade and establish diplomatic relations with Native American tribes. Long's command was to map the Missouri and its tributaries and document the landscapes, plants, animals and native people encountered. When congressional cutbacks stopped the Missouri Expedition at Council Bluff in what is now eastern Nebraska ${ }^{1}$, Long's party of 22 soldiers, topographers, naturalists and guides was detached from the main force and provided with a new mandate to follow the Platte River to its source in the Rocky Mountains, work its way south to explore the sources of the Red and Arkansas rivers and follow those streams to their confluences with the Mississippi. ${ }^{2}$ The Red River was of particular interest, because it marked part of the disputed south-western boundary of the newly-acquired Louisiana Territory, but its course remained mostly speculative. Long's expedition was the sixth government-sponsored exploring party to travel through the Louisiana Territory, following Meriwether Lewis and William Clark's expedition to the north-western coast of North America in 1804-1806; William Dunbar 
and George Hunter's exploration and mapping of the Ouachita River in the fall and winter of 1804-1805; Zebulon M. Pike's journeys to the headwaters of the Mississippi (1805-1806) and Arkansas (1806-1807) rivers; and Thomas Freeman and Peter Custis's aborted attempt to ascend the Red River in 1806. Although scientific discovery played a role on each of the previous expeditions, it was emphasized at the highest levels of the military in Long's expedition. In a letter dated 6 January 1819 to Congressman (and botanist) William Darlington, Secretary of War John Caldwell Calhoun stated, "The original objective of the expedition was to extend the knowledge of the Geography of our country; but it has been determined to make it as subservient to science, as possible" (Darlington 1843: 296). Calhoun consulted the American Philosophical Society regarding the objectives of the expedition $^{3}$, and he specifically mandated the description and documentation of regional natural history in his orders to the expedition's members (James 1822).

The funding cuts that stopped the Missouri Expedition, however, left the scientific expedition under-manned and poorly outfitted for its long overland journey and ambitious objectives. The men endured numerous set-backs and deprivations along the way and at the end, they had not achieved most of their primary exploratory goals. Most notably, the expedition did not find the sources of the Platte or Arkansas rivers, and they missed the Red River entirely (James 1822). Many historians considered the expedition a disappointment (for example, Nichols and Halley 1980), or even a complete failure (for example, Riegel and Athearn 1971). Scientifically, however, the contributions from Long's expedition were significant, providing important new insights regarding the native peoples and the natural history of the western territories (Goodman and Lawson 1995; Genoways and Ratcliffe 2008; Woodman 2009).

An account of Long's expedition was compiled for the public by Edwin James, the botanist, geologist and surgeon for the expedition, from notebooks, documents, recollections and additional information supplied by other members of the party, especially Long and the expedition's zoologist, Thomas Say. This work was published in Philadelphia by H. C. Carey and I. Lea (James 1822) and in London by Longman, Hurst, Rees, Orme \& Brown (James 1823) as Account of an expedition from Pittsburg to the Rocky Mountains (hereafter the Account). The Account was written in the form of a daily journal, recording routes of travel, encounters with native groups and the landscapes and geology of the region. The work reported upon the animals and plants encountered, and included descriptions of 43 new animals and eleven fossils by Say and 13 new plants by James (James 1822, 1823; Goodman and Lawson, 1995; Woodman 2009).

Two aspects of the publication of the Account are relevant to biologists because of their potential impact on the nomenclature of the species first described in it. The first is the existence of two editions, both of which are generally considered to have been published in 1823 (for example, Meisel 1926; Stafleu and Cowan 1979). The Philadelphia and London editions of the Account differ substantially in format ${ }^{4}$ and, more importantly, content (Nichols and Halley 1980; Haltman 2008). ${ }^{5}$ Species are described in a different order in the two editions and some of the descriptions vary. Differences between the two editions can be confused by relying upon the more readily available 1905 reprint of the Account (Thwaites 1905), which is based on the main text of the London edition, but contains additions from the Philadelphia edition.

A second potential area of confusion concerns the dates of publication ${ }^{6}$ of the two editions, which is relevant because most of the new species are named and described in both. In general, the Philadelphia edition of the Account is treated as the earlier text, possibly 
because James compiled the report in Philadelphia and Long was in direct contact with the Philadelphia publishers. The expressed intent of Carey \& Lea and their associates in London, however, was to publish the Account simultaneously in the United States and Great Britain (Anonymous 1823e, Clarke 1823). Unfortunately, no explicit publication records exist, and uncertainty regarding the dating of the two editions of the Account is apparent in the biological and historical literature. The frontispieces in the two text volumes of the Philadelphia edition are printed with the year 1823, whereas the appendix to the second volume and the atlas volume bear the year 1822. Several sources indicate that part (Weiss and Ziegler 1931; Hubach 1998; Branch 2004) or all (Etulain 1987; Stroud 1992) of the Philadelphia edition was published in 1822. In contrast, at least one publication indicated that the London edition was published several years prior to the Philadelphia edition (Osterhout 1923). These issues are further confused by the large number of popular and authoritative works that incorrectly cite Long rather than James as the compiler of the text (for example, Bachman 1837; Hall 1981; Wilson and Reeder 1993), an error also made in the past by some libraries (Anonymous 1825).

The history of the Philadelphia edition of the Account is recorded to a large extent in the correspondence of Long, Calhoun and others (Wood 1966; Nichols and Halley 1980; Benson 1988). To my knowledge, however, there has been no attempt to trace the publication of the London edition or to determine whether the publishers realized their intent of simultaneous publication. I reviewed a variety of contemporary sources, including correspondence, magazines and journals, to determine as closely as possible the dates on which the Philadelphia and London editions of the Account were made available to the public in order to establish the priority of their publication and, thereby, the correct authority for the new taxa described in this work.

\section{PUBLICATION OF THE PHILADELPHIA EDITION}

Secretary of War Calhoun proposed that Long prepare a popular account of his expedition and instructed him to determine how much publication of the work would cost. ${ }^{7}$ Long requested the assistance of James and Say, and in mid-November 1821, James began compiling the manuscript for the Account (James 1822). The manuscript was completed about the middle of June $1822 .^{8}$

The August 1822 issue of Philadelphia's Port-folio (Hall 1822) reported that the Account was in press and was expected in September. ${ }^{9}$ In anticipation of its publication, select editors were provided access to some pages of the Account, and in September extracts from the work began to circulate among newspapers and magazines in the United States (Anonymous 1822a). ${ }^{10}$ Delays plagued the publication, however, and in October, the Account was still not published (Everett 1822). On 10 October 1822, Long reported that the publisher Carey \& Lea had promised to print a minimum of 80 pages per day, but was producing fewer than half that number. Carey \& Lea apologetically explained "that their Paper maker has failed to supply them according to contract and they can procure no paper of suitable character elsewhere." 11 By early December, "about fifty pages" remained to be printed, ${ }^{12}$ and then the binder was unable to obtain sufficient supplies to fulfill his contract. ${ }^{13}$ As publishers, Carey \& Lea co-ordinated a variety of other businesses that carried out the actual editing, printing, binding and distribution of their books. ${ }^{14}$ A large portion of their assets were tied up in book stock and credit extended to those businesses and the publishers were feeling a financial 
strain. As a result, they cut back on their work in 1823, printing only 28 new titles in contrast to 42 new titles in 1822 . They also gave priority of their presses to projects that promised to be more remunerative. ${ }^{15}$

From 17 through 31 December 1822, Philadelphia's National gazette printed a daily advertisement from Carey \& Lea indicating the Account would be published "next week" (Anonymous 1822b). On 21 December Long sent a bound copy of the Account to Secretary Calhoun, writing, "I embrace the earliest opportunity to transmit a Copy of the "Account of the Expedition' and will forward eleven others as soon as the work shall have been published, which will complete the dozen ordered in your instructions of November 1821."16 Despite Long's early access to the Philadelphia edition, print sources indicate that the work was not publicly available until about ten days later. On 31 December, the National gazette printed the last notice announcing the Account would be published "next week" (Anonymous 1822b). On the preceding page of the same issue, Carey \& Lea have a new advertisement, indicating the Account was published "this day" (Anonymous 1822c). This conflicting information from the publisher is resolved by a third advertisement that appears a little below this notice, indicating that copies of the Account had been received and were for sale at the bookseller "Abm. Small" on Chestnut Street (Anonymous 1822d). Two additional booksellers in Philadelphia began advertising the Account on 3 January 1823 (Anonymous 1823a) and 11 January (Anonymous 1823c).

By 3 January, Long had enough copies to fulfill his obligation to the War Department, and he sent these to Secretary Calhoun:

I transmit by this days mail, six copies of the "Account" of the late Expedition under my command, being the residue of the Dozen Copies which you have instructed me to furnish to the War Department. They would have been forwarded at an earlier period, but that the publishers could not obtain sufficient supplies from the Binding to answer the numerous demands for the work. ${ }^{17}$

The same day, Long presented a copy to the American Philosophical Society in Philadelphia. ${ }^{18}$ The Account was available in bookstores in Baltimore, Maryland, by 7 January (Anonymous 1823b), in the District of Columbia by 10 January (Gales and Seaton 1823), and in New York City by 11 January (Eastburn 1823). Distribution to New England was delayed, the first bookstores in Boston, Massachusetts, not advertising copies for sale until mid-February (Anonymous 1823h). At least one copy of the Philadelphia edition reached London as early as 27 February, when a set was donated to the Royal Society of London by one of its fellows. ${ }^{19}$

Contemporary advertisements before and after its publication describe the Philadelphia edition as consisting of two octavo volumes of text accompanied by a quarto volume of plates and maps for the price of $\$ 9 .{ }^{20}$ There is no indication at any time of any of the three volumes being sold separately. The release and sale of the Account as a three-book set is relevant because it indicates that all three volumes were published and available at the same time despite the different dates printed on their title pages.

\section{PUBLICATION OF THE LONDON EDITION}

Announcements of the imminent publication of the Account in London began to appear in mid-January 1823, with a predicted publication date "early in February" (Anonymous 1823d). A notice in the Literary gazette on 15 February promised that the work would 
appear "before the expiration of the month" (Jerdan 1823c: 109), whereas notices in the Morning chronicle and The Times fixed the date as 24 February (Anonymous 1823f, 1823g). On 26 February, the Morning chronicle announced that the Account was published "on this day" (Anonymous 1823i: 1). The weekly Literary gazette of 1 March confirmed the publication, indicating that the Account had been published since their previous issue on 22 February (Jerdan 1823d). That magazine also published an extract, noting that "three octavo volumes are not to be digested in one week; but we can cut up a few slices and dress them up into a dish wherewith to entertain our friends" (Jerdan 1823a: 131-132). A number of other periodicals also noted the publication of the Account in their March issues. As late as March, however, European magazine and Eclectic review listed the London edition as still in press (Fielding 1823; Conder 1823a). Part of the confusion was that periodicals on both sides of the Atlantic often mangled the title or misidentified the author. The March 1823 issue of London magazine, for example, listed "Major Long's Exploratory Travels to the Rocky Mountains of America" as a work in press, while it noted "An Expedition from Pittsburgh to the Rocky Mountains ... by Edwin James" as a work "lately published" on the facing page (Scott and Taylor 1823a: 365-366). A similar expansion of the Account into two different titles, neither completely correct, occurred in the Edinburgh magazine (Constable 1823). Contemporary advertisements indicate that the three octavo volumes, illustrated with maps and plates, sold for the price of $£ 16 s$. 0d., approximately two-thirds the price in the United States. ${ }^{21}$ Coming full circle, the National advocate of New York City carried an advertisement on 22 April 1823, announcing the London edition for sale in New York City (Noah 1823).

Although the expressed intent was to publish the Account at the same time in Philadelphia and London, notices in British newspapers and magazines indicate that the London edition did not appear until two months after the Philadelphia edition, probably on 26 February 1823, but certainly between 24 and 28 February. Given the slow trans-Atlantic communication at that time, two months may not have been far outside the concept of simultaneity for that era. The earlier publication of the Philadelphia edition is also implied by several British reviewers who viewed the London edition as "a reprint" (Conder 1823b: 481) or even "a mutilated reprint of the American edition" (Scott and Taylor 1823b: 428).

Considering the political climate, it may seem surprising that the United States War Department supported the publication of the Account in London, inclusive of its detailed maps and report on the resources of the western territory. The London edition, in fact, contains a more complete version of Long's original report to the War Department than the Philadelphia edition (Thwaites 1905). Although the mostly inconclusive War of 1812 between the United States and Great Britain (which actually lasted from June 1812 to February 1815) was mostly ignored in Great Britain, it had witnessed the capture and burning of the United States capital and was not yet a distant memory for Americans in 1823. The United States government viewed British policy in north-western North America as antagonistic to its own. British fur trading interests continued to encroach on the northwestern territory claimed by the United States, and its agents stirred up the sentiments of the native tribes against American traders and settlements (James 1822; Goodwin 1917; Wesley 1931; Hemphill 1971). Calhoun probably supported publication of the London edition to help solidify American claims to the region and to build up the reputation of the young nation in Europe. ${ }^{22}$ If so, the sentiments expressed by some of the London journals suggests that he generally succeeded. Although the Account would not be expected to spark the nationalistic pride that it did in the United States, publication of the London edition was 
broadly noted in Great Britain. Publication notices appeared in at least eleven London periodicals and in those of cities as distant as Edinburgh. The Literary gazette published extracts in six separate issues (Jerdan 1823a, 1823b), and the Account was reviewed in respected literary magazines such as Eclectic review (Conder 1823b), London magazine (Scott and Taylor 1823b), Monthly review (Anonymous 1823k, 18231) and Quarterly review (Anonymous 1823j). In an era when American literature was more typically viewed with disapproval in Great Britain (Anonymous 1820, Smyth 1892), British reviewers wrote with grudgingly qualified praise. Like their American counterparts, they lauded the accomplishments and personnel of the expedition, although they were less enthusiastic about the Account's literary style. The London magazine noted, "In closing these volumes, we cannot but applaud the zeal, perseverance and intelligence of the gentlemen composing the Expedition" (Scott and Taylor 1823b: 428). Conder (1823b: 481), in the Eclectic review, wrote

The Expedition of which an account is here given, does honour to the American Government and to the gentlemen to whom its execution was confided. Although not equal in interest or in the importance of its results, to that undertaken by Captains Lewis and Clarke in 1804-06. [sic], it has added considerably to our knowledge of the country west of the Mississippi.

In short, the notice received by the London edition in the press focused positive attention on Long's expedition, thereby courting British public opinion favorable to American interests.

The availability of the Philadelphia edition for purchase on 31 December 1822 and the publication of the London edition about 26 February 1823, confirm the assumed sequence of publication of the two editions of the Account. Because the Philadelphia edition appeared first, it is the authority for most new species named in the Account. The correct year of publication of the Philadelphia edition, generally assumed to be 1823, is in fact 1822, further distinguishing the two editions and establishing the priority of the Philadelphia edition for new species named and described in it.

\section{ACKNOWLEDGEMENTS}

I thank Leslie Overstreet and Daria A. Wingreen, Joseph F. Cullman $3^{\text {rd }}$ Library of Natural History, National Museum of Natural History, Washington; Kirsten van der Veen, Dibner Library of the History of Science and Technology, National Museum of American History, Washington; and numerous librarians in the Newspaper and Current Periodicals Reading Room, Library of Congress, Washington, who provided access to the valuable materials under their care. Kamila Reekie, General and Zoology Library, Natural History Museum, London; Malcolm P. Marjoram, British \& Early Printed Collection, British Library, London; Roy E. Goodman, American Philosophical Society, Philadelphia; Phil Lapsansky, Reading Room, The Library Company, Philadelphia; and Eileen Mathias, Ewell Sale Stewart Library, Academy of Natural Sciences of Philadelphia, responded graciously to requests regarding their holdings with valuable, detailed information. Sandy Feinstein, Chandler S. Robbins, Robert M. Timm and an anonymous reviewer provided valuable comments on previous versions of this manuscript.

Any use of trade, product, or firm names is for descriptive purposes only and does not imply endorsement by the United States government.

\section{NOTES}

${ }^{1}$ Council Bluff is a topographic feature in eastern Nebraska that is sometimes mistaken in the literature for the city of Council Bluffs, Iowa. See Genoways and Ratcliffe (2008) for the location of the former. 
${ }^{2}$ J. C. Calhoun (hereafter JCC) to S. H. Long (hereafter SHL), 29 February 1820: United States National Archives, Washington, DC (hereafter USNA), Records Group 107: Office of the Secretary of War (hereafter SW), Letters Sent, Military Affairs, 1800-1884 (hereafter LS)], 11: 4-5.

3 JCC to R. Walsh, 11 March 1819: USNA, SW, LS, 10: 271.

${ }^{4}$ The complete title of the Philadelphia edition (James 1822) is

Account of an expedition from Pittsburgh to the Rocky Mountains, performed in the years 1819 and '20, by order of the Hon. J. C. Calhoun, Sec'y of War: under the command of Major Stephen H. Long. From the notes of Major Long, Mr. T. Say, and other gentlemen of the exploring party. Compiled by Edwin James, botanist and geologist for the expedition. In two vols. - with an atlas.

This edition consists of two octavo volumes of text with a separate quarto volume containing two maps, two geological cross-sections and eight engraved plates.

The title of London edition (James 1823) is slightly different:

Account of an expedition from Pittsburgh to the Rocky Mountains, performed in the years 1819, 1820. By order of the Hon. J. C. Calhoun, Secretary of War, under the command of Maj. S. H. Long, of the United States Top. Engineers. Compiled from the notes of Major Long, Mr. T. Say, and other gentlemen of the party by Edwin James, botanist and geologist to the expedition. In three volumes.

The London edition has one map, a single geological chart and nine plates scattered throughout three volumes of text. Three of the plates in the Philadelphia edition and four of the plates in the London edition do not occur in the other edition. Other superficial differences include variations in chapter contents and the location of the footnotes in the Philadelphia edition as endnotes in the London edition.

${ }^{5}$ Among other things, the London edition was bowdlerized to remove sections concerning adultery, rape, homosexuality and prostitution among native tribes (Haltman 2008).

${ }^{6}$ According to the International code of botanical nomenclature, publication "is effected ... only by distribution of printed matter (through sale, exchange, or gift) to the general public or at least to botanical institutions with libraries accessible to botanists generally", and the "date of effective publication is the date on which the printed matter became available ..." (McNeill et al. 2006: articles 29 and 31). In zoology, the date of publication is "the date on which copies of the work become available by purchase or free distribution" (ICZN 1999: 102).

${ }^{7}$ Some histories state that Long proposed publication of the popular version of the expedition report to Calhoun (Wood 1966; Nichols and Halley 1980). The correspondence, however, indicates that Long was initially focused on publishing a map he was then drafting. It was Calhoun who considered it desirable to publish a report, a point he mentioned in a letter to Jedidiah Morse (JCC to J. Morse, 18 June 1821: USNA, Records Group 75: Bureau of Indian Affairs, Letters Sent by the Secretary of War Relating to Indian Affairs, 1800-1824, E: 118-119). Calhoun broached the subject to Long on 31 July 1821, noting: "It would seem desirable that a detailed account of the expedition should be laid before the public in a popular form, provided that sufficient patronage can be obtained to justify the expense" (JCC to SHL, 31 July 1821: USNA, SW, LS, 11: 268). Long, who was ill at the time, did not respond and Calhoun repeated his suggestion more forcefully on 8 October (JCC to SHL, 8 October 1821: USNA, SW, LS, 11: 299-300). When Long answered, he had located a publisher, writing, "there is a prospect of our being able to publish, agreeably to your views, without additional expense to the Government ..." (SHL to JCC, 30 October 1821: USNA, SW, Letters Received, Main Series, 1801-1860 (hereafter LR), L-58). Calhoun subscribed the War Department to 12 copies of the Account (JCC to SHL, 17 November 1821: USNA, SW, LS, 11: 317).

${ }^{8}$ M. Benson, 1968 Edwin James: scientist, linguist, humanitarian. Unpublished doctoral dissertation, University of Colorado. Ann Arbor: University Microfilms, Inc.

${ }^{9}$ M. Benson, 1968: pp 95-96 (note 8).

${ }^{10}$ Although some historians indicate that there was "limited enthusiasm" about Long's expedition upon its return from the west (for example, Nichols and Halley 1980: 161), reports from the expedition in the form of extracts from the Philadelphia edition were widely published and re-published in periodicals from Maine to Florida and from New York to Arkansas. From September 1822 through November 1824, I counted 16 distinct extracts circulated among 37 American and one British periodical. These numbers are conservative, limited by the number of digitized and searchable periodicals for the time period of interest and available to me in 2007 and 2008. Not surprisingly, the greatest numbers were published in January and February 1823.

${ }^{11}$ M. Benson, 1968: p. 96 (note 8). 
12 M. Benson, 1968: p. 97 (note 8).

${ }^{13}$ SHL to JCC, 3 January 1823: USNA, SW, LR, L-54.

${ }^{14}$ During their peak years 1826-1838, Carey \& Lea employed more than 40 printing establishments from Massachusetts to Maryland. Many of their established printers also acted as booksellers (Kaser 1957).

${ }^{15}$ Kaser (1957: 29) noted that "two major projects required the full attention of the firm during 1822 and 1823. These were the issuing of the American Atlas and the quarto Bible." Both the atlas, published in July 1822, and the bible, published 8 January 1823, were fully subscribed despite their high prices. In South Carolina alone, their agent obtained 100 subscribers for the $\$ 20$ atlas and nearly 200 for the $\$ 30$ bible. The attentions and resources of the publishers naturally would be focused more on pre-paid volumes with a guaranteed profit margin than on works of more specialized interest, such as the Account.

${ }^{16}$ SHL to JCC, 21 December 1822: USNA, SW, LR, L-50.

${ }^{17}$ SHL to JCC, January 3, 1823: USNA, SW, LR, L-54.

${ }^{18}$ Roy E. Goodman, pers. comm., 19 April 2005. I found no evidence that Long donated copies of the Account to other Philadelphia institutions. The single copy of the Philadelphia edition in the Academy of Natural Sciences of Philadelphia (ANSP) is from Robert Eglesfeld Griffiths, who bequeathed his library and collections to ANSP in 1850 (Phillips and Phillips 1963). One of The Library Company of Philadelphia's two copies of the two volumes of text was purchased from Littell \& Henry Booksellers and Stationers before 1825 (Anonymous 1825); the second is from F. Prime, Jr., probably donated by his estate after his death in 1915. An unrelated copy of the atlas was donated by Mrs. H. Lea Hudson in 1985.

${ }^{19}$ Dr Hosac presented a copy of the Philadelphia edition to the Royal Society of London on 27 February 1823 (Anonymous $1823 \mathrm{~m}$ ), although the Society did report having the London edition as late as 1883 (Anonymous 1883). The Linnean Society of London did not record having a copy of either edition as late as 1896 (Anonymous 1896). The British Library (then the British Museum) obtained its copy of the London edition in the early 1830s and the Philadelphia edition in 1846 (M. P. Marjoram, pers. comm., 10 March 2005). The copies of the London and Philadelphia editions now in the libraries of the Natural History Museum, London, were purchased its in 1885 and 1886, respectively (K. Reekie, pers. comm., 9 March 2005).

${ }^{20}$ The price for the Account seems reasonable compared to Carey \& Lea's \$20 American atlas and \$30 quarto Bible.

${ }^{21}$ Based on an estimated average CPI/RPI exchange rate of $£ 1=\$ 4.76$ in 1830 . URL (accessed 11 November 2008): http://www.measuringworth.com/exchange/ (L. H. Officer and S. H. Williamson, 2008 Computing 'real value' over time with a conversion between U. K. pounds and U. S. dollars, 1830-2007. MeasuringWorth).

22 JCC to SHL, 8 March 1819: USNA, SW, LS, 10: 267-268: "Great confidence is reposed in the acquirements and zeal of the citizens who will accompany the expedition for scientifick [sic] purposes; and a confident hope is entertained that their duties will be performed in such a manner as to add both to their own reputation and that of our country." See also Goetzmann (1966: 57-58).

\section{REFERENCES}

ANONYMOUS, 1820 British notices of American Literature. Analectic magazine 1 (4): 341-344.

ANONYMOUS, 1822a Extracts from the History of the Expedition from Pittsburgh .... National gazette and literary register 3 (588): 1-2.

ANONYMOUS, 1822b [Advertisement] Major Long's expedition. Next week will be published ... . National gazette and literary register 3 (659-671): 3-4.

ANONYMOUS, 1822c [Advertisement] Expedition to the Rocky Mountains. This day is published .... National gazette and literary register 3 (671): 3, column 1 .

ANONYMOUS, 1822d [Advertisement] Major Long's expedition. Just received and for sale ... . National gazette and literary register 3 (671): 3, column 1.

ANONYMOUS, 1823a [Advertisement] New books. For sale by A. Finley. National gazette and literary register 3 (674): 3, column 1.

ANONYMOUS, 1823b [Advertisements] New works $\mid$ New publications | Just received ... . Baltimore patriot and mercantile advertiser 21 (4): 3, columns 1-3. 
ANONYMOUS, 1823c [Advertisement] J. Mortimer's. Who has on sale ... . National gazette and literary register 3 (681): 3, column 1.

ANONYMOUS, 1823d [Advertisement] Books published this day. Morning chronicle 16768 (16 January): 2, column 1.

ANONYMOUS, 1823e. The mirror of fashion. Morning chronicle 16778 (28 January): 3, column 2.

ANONYMOUS, 1823f [Advertisement] Books published this day. Morning chronicle 16786 (6 February): 1 , column 5 .

ANONYMOUS, 1823g [Advertisement] Exploratory travels. The Times (London) 11789 (7 February): 3, column 4.

ANONYMOUS, 1823h [Advertisement] Major Long's expedition Columbian centinel 4055 (19 February): 3 , column 3.

ANONYMOUS, 1823i [Advertisement] Books published this day. Morning chronicle 16803 (26 February): 1 , column 4.

ANONYMOUS, 1823j Account of an expedition from Pittsburgh to the Rocky Mountains ... . Quarterly review 29 (57): 1-25.

ANONYMOUS, 1823k Account of an expedition from Pittsburgh to the Rocky Mountains ... . Monthly review or literary journal 101 (August): 337-352.

ANONYMOUS, 18231 Account of an Expedition from Pittsburgh to the Rocky Mountains. By Edwin James, \&c. Monthly review or literary journal 101 (September): 55-71.

ANONYMOUS, $1823 \mathrm{~m}$ Presents received by the Royal Society, from November 7th 1822, to June 19th 1823. With the names of the donors. Philosophical transactions of the Royal Society of London 113: 541-548.

ANONYMOUS, 1825 Sixth supplement to volume II - part II of the catalogue of books, belonging to the Library Company of Philadelphia. Philadelphia.

ANONYMOUS, 1883 Catalogue of the scientific books in the library of the Royal Society: general catalogue. London.

ANONYMOUS, 1896 Catalogue of the library of the Linnean Society of London. London.

BACHMAN, J., 1837 Some remarks on the genus Sorex, with a monograph of the North American species. Journal of the Academy of Natural Sciences of Philadelphia 7: 362-402, plates 23-24.

BENSON, M. (editor), 1988 From Pittsburgh to the Rocky Mountains. Golden, Colorado.

BRANCH, M. P. (editor), 2004 Reading the roots. American nature writing before Walden. Athens, Georgia.

CLARKE, T. C. (editor), 1823 Literary. Saturday evening post 2 (2): 2.

CONDER, J. (editor), 1823a Select literary information. Eclectic review 19: 286-287.

CONDER, J. (editor), 1823b Account of an expedition from Pittsburgh to the Rocky Mountains .... Eclectic review 19: 481-501.

CONSTABLE, A. (editor), 1823 Works preparing for publication | Monthly list of new publications. Edinburgh magazine and literary miscellany 12: 361-366.

DARLINGTON, W., 1843 Reliquiae Baldwinianae: selections from the correspondence of the late William Baldwin, M.D. Philadelphia.

EASTBURN, J. (editor), 1823 [Advertisement] Interesting expedition. Albion 1 (30): 240.

ETULAIN, R. W., 1987 Chronology, pp xxi-xliii in TAYLOR, J. G., LYON, T. J., DAY, G. F., HASLAM, G. W., MAGUIRE, J. H. and PILKINGTON, W. T. (editors), A literary history of the American west. Fort Worth, Texas.

EVERETT, E. (editor), 1822 Quarterly list of new publications. North American review 5 (12): 487-490.

FIELDING, J. (editor), 1823 Works in press. European magazine 83: 179.

GALES, J. jr. and SEATON, W. W. (editors), 1823 [Advertisement] Just received and for sale by Davis \& Force .... Daily national intelligencer 11 (3117): 3.

GENOWAYS, H. H. and RATCLIFFE, B. C., 2008 Engineer Cantonment, Missouri Territory, 1819-1820: America's first biodiversity inventory. Great Plains research 18: 3-31.

GOETZMANN, W. H., 1966 Exploration and empire. New York.

GOODMAN, G. J. and LAWSON, C. A., 1995 Retracing Major Stephen H. Long's 1820 expedition. Norman, Oklahoma. 
GOODWIN, C., 1917 A larger view of the Yellowstone Expedition. Mississippi Valley historical review 4: 299-313.

HALL, E. R., 1981 The mammals of North America. New York.

HALL, J. E. (editor), 1822 Literary intelligence. Port-folio 2 (256): 176.

HALTMAN, K., 2008 Looking close and seeing far: Samuel Seymour, Titian Ramsay Peale and the art of the Long expedition, 1818-1823. University Park, Pennsylvania.

HEMPHILL, W. E. (editor), 1971 The papers of John C. Calhoun. Volume 5. 1820-1821. Columbia, South Carolina.

HUBACH, R. R., 1998 Early Midwestern travel narratives: an annotated bibliography, 1634-1850. Reissue of 1961 edition, edited by J. C. Dann. Detroit.

ICZN (International Commission on Zoological Nomenclature), 1999 International code of zoological nomenclature. Fourth edition. London.

JAMES, E. (compiler), 1822 Account of an expedition from Pittsburgh to the Rocky Mountains, performed in the years 1819 and '20, by order of the Hon. J. C. Calhoun, Sec'y of War: under the command of Major Stephen H. Long. From the notes of Major Long, Mr. T. Say, and other gentlemen of the exploring party. Compiled by Edwin James, botanist and geologist for the expedition. In two vols. - with an atlas. Philadelphia.

JAMES, E. (compiler), 1823 Account of an expedition from Pittsburgh to the Rocky Mountains, performed in the years 1819, 1820. By order of the Hon. J. C. Calhoun, Secretary of War, under the command of Maj. S. H. Long, of the United States Top. Engineers. Compiled from the notes of Major Long, Mr. T. Say, and other gentlemen of the party by Edwin James, botanist and geologist to the expedition. In three volumes. London.

JERDAN, W. (editor), 1823a Account of an expedition from Pittsburgh to the Rocky Mountains ... Literary gazette 319: 131-132.

JERDAN, W. (editor), 1823b James' Expedition to the Rocky Mountains. Literary gazette 320-323, 327: 150-152, 167-168, 182-184, 200-201, 263-264.

JERDAN, W. (editor), 1823c Literary intelligence. Literary gazette 317: 109.

JERDAN, W. (editor), 1823d List of works published since our last. Literary gazette 319: 142.

KASER, D., 1957 Messrs. Carey and Lea of Philadelphia. A study in the history of the booktrade. Philadelphia.

McNEILL, J., BARRIE, F. R., BURDET, H. M., DEMOULIN, V., HAWKSWORTH, D. L., MARHOLD, K., NICOLSON, D. H., PRADO, J., SILVA, P. C., SKOG, J. E., WIERSEMA, J. H., and TURLAND, N. J. (editors), 2006 International code of botanical nomenclature (Vienna code). Ruggell.

MEISEL, M., 1926. A bibliography of American natural history. New York. (Facsimile 1967. New York.)

NICHOLS, R. L. and HALLEY, P. L., 1980 Stephen Long and American frontier exploration. Newark, Delaware.

NOAH, M. M. (editor), 1823 Advertisements. National advocate, for the country 11 (1056): 5.

OSTERHOUT, G. E., 1923 What is Geranium caespitosum James? Bulletin of the Torrey Botanical Club 50: 81-84.

PHILliPS, V. T. and PHILliPS, M. E., 1963 Guide to the manuscript collections in the Academy of Natural Sciences of Philadelphia. Special publication of the Academy of Natural Sciences of Philadelphia 5: 1-553.

RIEGEL, R. E. and ATHEARN, R. G., 1971 America moves west. Fifth edition. New York.

SCOTT, J. and TAYLOR, J. (editors), 1823a Literary intelligence | Works lately published. London magazine 7: 365-366.

SCOTT, J. and TAYLOR, J. (editors), 1823b Expedition from Pittsburgh to the Rocky Mountains. London magazine 7: 422-428.

SMYTH, A. H., 1892 The Philadelphia magazines and their contributors. Philadelphia.

STAFLEU, F. A. and COWAN, R. S., 1979 Taxonomic literature. Volume 2. H-Le. Second edition. Utrecht.

STROUD, P. T., 1992 Thomas Say, New World naturalist. Philadelphia.

THWAITES, R. G. (editor), 1905 Early western travels 1748-1846. Volumes 14-17. Account of an expedition from Pittsburgh to the Rocky Mountains. Cleveland.

WEISS, H. B. and ZIEGLER, G. M., 1931 Thomas Say, early American naturalist. Baltimore.

WESLEY, E. B., 1931 A still larger view of the so-called Yellowstone Expedition. North Dakota historical quarterly 5: 219-238. 
WILSON, D. E. and REEDER, D. M. (editors), 1993 Mammal species of the world. A taxonomic and geographic reference. Second edition. Washington.

WOOD, R. G., 1966 Stephen Harriman Long 1784-1864. Army engineer, explorer, inventor. Glendale, California.

WOODMAN, N., 2009 The Stephen H. Long Expedition (1819-1820), Titian R. Peale's field illustrations and the lost holotypes of the North American shrews Sorex brevicaudus Say and Sorex parvus Say (Mammalia: Soricidae) from the Philadelphia Museum. Proceedings of the Biological Society of Washington 122: 117-129

Received 22 January 2009. Accepted 23 July 2009. 